\title{
Environment-Based School Curriculum as a Character Forming Care Environment
}

\author{
Rabiatul Adawiah
}

\author{
Pancasila and Civic Education Study Program Faculty of Teacher Training and Education, \\ Lambung Mangkurat University, Banjarmasin, Indonesia \\ Corresponding author. Email: rabiatuladawiah@ulm.ac.id
}

\begin{abstract}
In the education system, the curriculum has a very strategic role in realizing quality schools. A good curriculum will create a quality school, and a quality school will provide education according to the needs of the community. One need that is felt to be very urgent is the formation of attitudes and behavior of people who care about the environment. The environment-based curriculum is a manifestation of one of the components in the Adiwiyata program that has been implemented since 2006. This program is certainly very good to implement, but in reality some schools do not implement the program properly. The purpose of this study is to determine the application of the environmentally based school curriculum. and student care for the environment. This research uses a qualitative approach. The research was conducted on schools that have Adiwiyata school status in Balangan Regency. Data collection was carried out by interview, observation and documentation techniques. The data obtained were analyzed using the interactive model analysis technique from Miles and Huberman. The results showed that only some schools consistently and consistently implemented an environment-based curriculum and some others only started running the Adiwiyata program at the beginning. In the Learning Implementation Plan (RPP) document it integrates with the values of caring for the environment but it is not implemented properly. Student concern for the environment, $38.5 \%$ showed very good concern, $45 \%$ showed concern, and $12 \%$ showed concern by the criteria enough.
\end{abstract}

Keywords: Curriculum, Environment-Based, Character.

\section{INTRODUCTION}

Education has various benefits, one of which is supporting activities to save the earth and manage the environment. The environment is an environment consisting of living things and other components in it. According to [1] the environment is a combination of all the things around us that affect our life. Based on this statement, the quality of the environment must be maintained. Environmental Law No. 32 of 2009 article 1 states that the environment is a spatial unit with all objects, forces, conditions and living things, including humans and their behavior, which affect the continuity of life and the welfare of humans and other living creatures. Cleanliness and health of the school environment need to be realized as a form of togetherness between the world of education and the government.

To raise human awareness of the environment around it, the most important and must-do process is to touch the heart. If the awareness process has occurred and a change in attitude and mindset towards the environment has occurred, it can be done to increase knowledge and understanding of the environment, as well as increase skills in managing the environment. The Indonesian government makes a policy that is implemented in the world of education as stated in article 65 point four of Law Number 32 Year 2009 concerning Environmental Protection and Management. Where in the article it explains that "everyone has the right and role in environmental management".

Responding to these problems and to increase knowledge and understanding of the environment to students and the community, on June 3, 2005, a Memorandum of Understanding was signed between the State Minister for the Environment and the Minister for National Education. The realization of the agreement, on February 21, 2006, the Adiwiyata Program was launched, namely a school that cares and has an environmental culture. According to Widaningsih [2] formally environmental education is an alternativerational to include environmental education in the curriculum. Environmental education is a wrong one factor urgent in success in management environment Life and too Becomes means that very urgent in produce source power human that can carry out the principle of sustainable development. Nurhani and Widodo [2] stated 
education environment needed and must Presented to child since early so that they understand and not spoil environment.

The Adiwiyata program is one of the strategies for providing environmental education by the government with the aim of creating schools that care and have an environmental culture. [3] said that every individual has the same obligation to protect the environment. Protecting the environment cannot be done alone, because this is a shared responsibility that needs to be done so that the earth and everything in it are not affected by the consequences of human actions themselves. Meobedient Ministry of Environment (2010) Adiwiyata program aims to realizing school members who are responsible for protecting and managing the environment through good school governance to support sustainable development.

The application of the Adiwiyata Program in education is because in the world of education it is easier to learn and apply various sciences, norms and ethics in achieving development goals. As saidAkpan et. al. [4] that the main concept To shape the behavior of people who care about the environment, three things are needed namely (1) institutional factors; (2) knowledge and values, and educational strategies, and the Adiwiyata program is is one of the government programs carried out through an education strategy. As stated by [5], it is a rational alternative to integrate environmental education into the curriculum is through environmental education. It goes on to say that environmental education is one of the factors that is very important to the success of environmental management and become a very important means of producing human resources who can implement the principles of sustainable development. In line with the above statement, Molina et al. [4] stated that the variable urgent to form behavior who care about the environment is through education, the higher one's knowledge, the more concerned about environmental problems. As said [6] stated that environmental education is processes aimed at shaping values, habits and behavior, to respect the environment. [7] adds that environmental education not only provides knowledge about the environment, but can also increase awareness and concern for environmental conditions.

In character building, concern for the environment is an important value to be cultivated. According to [8] that a human with character is a person who has concern for the environment, both the physical environment and the social environment.

\section{METHODS}

This research uses a qualitative approach. Moleong defines that qualitative research is scientific research, which aims to understand a phenomenon in a natural social context by promoting a deep communication interaction process between researchers and the phenomenon under study [9]. The research was conducted in Balangan Regency, with the selection of school samples purposive, that is for schools that have implemented the Adiwiyata program for at least three years. Data collection was carried out by using interview, observation and documentation techniques. The data obtained were analyzed by interactive model (interactive model of analysis) from Miles and Huberman. In this interactive analysis model the researcher moves to three components, namely data reduction (data reduction), presentation of data (display data) and drawing conclusions (verification).

\section{RESULTS AND DISCUSSION}

Implementation Basically, the environment-based curriculum is one of the components in the implementation of the Adiwiyata program in schools. However, it turns out that not all schools implement it continuously. As said by one of the speakers, Mr. S, who is the coordinator of the Adiwiyata team in an elementary school said that the environmentally based school curriculum in this school was implemented but now it is stagnant (not running well) because there was an issue that this school would be evicted, so this school was disturbed by this issue and the result was that the Adiwiyata program, especially the environmentally based school curriculum, was not working well."

The same thing was said by one of the Adiwiyata team and teachers at the school, he said that: "Regarding the integration of caring and environmental culture values in the curriculum and subjects, it is still not going well because some of the teachers in this school still do not understand. what a way to integrate into all subjects.

Almost the same thing also happened at SMAN 1 Juai, in that school the curriculum based on environmental care and culture did not work well, there were various factors behind the reasons why the curriculum did not work and that the curriculum was functioning properly, as said by Nasdi who is the adiwiyata team leader at the school, he said that In this school, the commitment to integrate a curriculum that contains the values of environmental care and culture in all subjects is still very low, this is because many teachers still do not understand how to integrate it into subjects, for example teachers in mathematics and sports are very difficult to link between math and sports with the environment.

In addition, he added, that the learning process in this school is normal like an ordinary school, even though this school is a Adiwiyata school but in the curriculum. still have difficulty in integrating environmental care values into all subjects. Then he also revealed several reasons why the teachers at the school were still unable to integrate into all subjects, because so far they had never received any training from either the Education Office, the Environment Service or schools that were already at the Adiwiyata level. national.

Researchers found slightly different things when conducting interviews and observations at SMPN 1 Juai. 
The principal of SMPN 1 Juai said that the SMP 1 Juai school had integrated the Adiwiyata program into the curriculum,but the implementation is still not optimal, because not all teachers and subjects can insert Adiwiyata programs into their teaching materials. Then he added that: "Subjects that have integrated the Adiwiyata program into their teaching materials are like Science because the subject of science is very close to the discussion of nature, so it is easy for teachers to associate teaching materials with the Adiwiyata program.

The same thing was also expressed by Mrs. Rina, who is a teacher of cultural arts at the school, and she is also one of the team in charge of the Adiwiyata program at the school, she said that: "I still cannot integrate the Adiwiyata Program into my subjects. maximally, because what I teach is very far from these themes, but sometimes if my teaching material can be related to the concept of the environment I will integrate it.

Based on the results of the interview above, it can be seen that in these schools the curriculum based on environmental care and culture is not running well, this can be seen from the statements from the principal and the teacher that only in science subjects teachers can integrate the Adiwiyata program in the learning process. , the rest for other subjects teachers still cannot integrate the Adiwiyata program into the learning process.

What was very different was that when the researchers visited three other schools, namely SDN Paringin Selatan 1, SMPN 4 Paringin, and SMKN PP Paringin, in these schools the curriculum program based on caring and environmental culture was really well implemented. into all subjects, and the existence of an independent monolithic Environmental Education subject is a compulsory subject taught in the school. As said by Mr. Hasan, who is the head of the team in charge of Adiwiyata at SDN 1 Paringin Selatan, he said that "this school has integrated the Adiwiyata program into the curriculum for learning methods, models and learning techniques always based on the Adiwiyata program,

Then he added that "to integrate the Adiwiyata program into these subjects the teacher must first load it into learning instruments such as syllabus, lesson plans and semester reports, then the learning instruments containing the Adiwiyata program are used as guidelines in implementing the learning process.

Thing In a similar vein, Mr. Edy, who is the head of the team in charge of the Adiwiyata program at SMPN 4 Paringin, said that: "Since 2010 it has been implemented, both in subjects and in the application of daily life. For example in the syllabus, in RPP, each subject is integrated with an environmental perspective, including in the subject we add subjects to support environmentally sound, namely Environmental Education. Including in RPP is inserted with environmental insight for all subjects, starting from Indonesian, PPKn , everything, even IPS. Then he continued that: "Since I am also a social studies teacher, I will also insert it, for example regarding the Green Revolution, besides that, values or insights about the environment will be inserted and applied and adjusted to the basic competencies of each." The opinion of Mr. Edy was strengthened by the Principal of SMPN 4 Paringin, who said that: "I always give recommendations to teachers to find out via the internet about learning materials, what their management is like, what is good, what methods are used in, for example, what kind of seed cultivation. Besides that, the learning resources that we can use can collaborate with the teachers concerned with the topic. Because research subjects like this also need information from various points of view, such as chemistry and biology teachers.

Likewise, what has been implemented by SMKN PP Paringin. Adiwiyata program team leader at the school, namely Mr Eko said that "as a teacher, you must play an active role in providing insight into the environment, especially for this subject, namely Environmental Education (PLH) which is taught in class X semester 1." Then he also added that "I happen to be a facilitator in subjects related to the Adiwiyata program. Namely Environmental Education. for the subject of Cultivation and Craftsmanship, it is actually PLH, it's just that because of the 2013 curriculum, we just changed the name. Based on the results of the interviews and observations above, it can be seen that the activities that have been carried out by Adiwiyata program schools in Balangan Regency related to integrating content with environmental care and culture in the curriculum can be seen:

1) Some schools that run the Adiwiyata Program in Balangan Regency have integrated the Adiwiyata program into all subjects taught.

2) Some schools and teachers have compiled learning tools such as syllabus, lesson plans, etc. with the theme of the environment.

3) Some schools have established a Monolithic Environmental Education (PLH) subject or stand alone as the subject being taught.

4) Develop local issues such as pollution, forest destruction, and global warming as learning materials

As is well known that general purpose Adiwiyata is to form a caring and environmentally cultured school that is able to participate in and carry out environmental conservation and sustainable development efforts for the benefit of present and future generations. In other words, creating good conditions for the school to become a place of learning and awareness for school residents, so that in the future the school community can take responsibility for efforts to save the environment and sustainable development.

To find out the attitudes and behavior of school residents in this study, especially students, the research team distributed questionnaires to 200 students selected to be the research sample. From the questionnaires that have been distributed, an overview of students' attitudes and behaviors related to the environment can be seen in the picture below. 


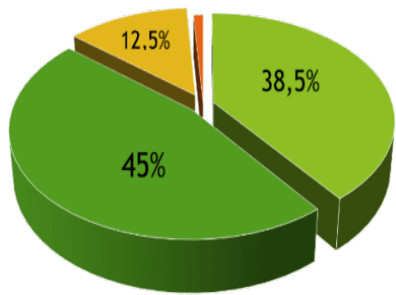

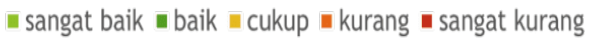

Figure. 1 Students Attitudes and Behaviour Related Environenment

From the picture above, it is known that the attitudes and behavior of students related to environmental management and protection are: $38.5 \%$ showed very good attitudes and behaviors, $45 \%$ showed good behavior, and $12 \%$ showed sufficient behavior.

Environment-based curriculum is a curriculum that contains material on environmental management and protection which is delivered in various ways in an effort to provide an understanding of the environment. This is as stated by [10] that an environment-based curriculum can be implemented in a simple way of delivering environmental material through a variety of curricula to provide an understanding of the environment that is linked in everyday life. The curriculum is organized to increase awareness of school members about environmental education. Environmental education plays an important role in shaping and spreading the values of loving the environment, so that harmony is achieved with the environment.

The environment-based curriculum developed by schools in an effort to protect and manage the environment is by integrating it with subjects. [11] states that examples of environmental materials that can be integrated into school subjects are physics, chemistry, biology, cultural anthropology, and geography. Almost all subjects in schools have been integrated with environmental insight. Besides being integrated with subjects, environmental education in schools also raises monolithic subjects, namely Environmental Education and the like.

There are several components that must be considered when developing an environment-based curriculum. Suharsimi in the AP Lecturer Team (2011) said that in general the curriculum consists of components of objectives, learning materials, learning and evaluation processes.

\subsection{Aim}

The goals in the curriculum are related to the results to be achieved, so they play an important role because they lead to all teaching activities to achieve predetermined goals, [7] says that one of the main goals to be achieved in environmental education is to help students understand the environment with the ultimate goal so that they have a concern in protecting and preserving the environment. Based on document search, both subjects integrated with environmental insight and monolithic subjects have different goals according to their respective basic competencies. One of the basic competencies in geography and social studies subjects is to show proactive behavior in learning the essence of geography and social studies to be applied in everyday life. The goal of these basic competencies is that students can explain the legal rules governing environmental management. The goals to be achieved through learning activities at school and outside school hours have developed cognitive aspects and also emphasize the formation of personalities or characters that love the environment. This is in accordance with the contents of the school's vision, that is, to produce graduates with an environmental perspective and natural disaster mitigation. Based on the objectives of these subjects, teachers as educators have developed environmental learning indicators.

\subsection{Study materials / teaching materials}

Teaching materials or subject matter must be adapted to the goals to be achieved by environmental education itself. The scope of material to be taught in Environmental Education should include those relating to human relations with the environment, both the natural environment and the social environment. Students are equipped with the ability to solve environmental problems and the actions that must be taken.

Yusuf [7] said that environmental education should contain: 1) contain essential and actual problems regarding population and the environment in people's lives; 2) can be used to develop attitudes, behaviors and personalities as Indonesian people with population and environmental insight; 3 ) has relevance to the level of development of students' interests, needs and abilities; 4) has relevance to the educational program described in the applicable curriculum; and 5) functions as a development and enrichment of existing educational programs in order to equip students to face and solve population and environmental problems.

Material on environmental insight has been integrated with the subjects, but only some schools and teachers have able to develop issues or problems regarding the environment into learning materials, so that students can solve environmental problems in everyday life. In addition to classroom learning, teachers also develop learning activities outside the classroom, namely through library studies and observation assignments. The results of observational studies are sometimes also used as environmental articles and then attached to school mading.

Environmental materials that are integrated into classroom learning are an effort to form a loving personality for the environment. Even though it was written in the lesson plan, it would be better for the teacher to also be an example in managing the school environment. 


\subsection{Learning Media}

Media learn is a all kinds of stimulants and tools that provided teacher to encourage students to learn (Nana Syaodiah in the AP Lecturer Team, 2011). The use of learning media in question depends on each subject. One form of using learning media in Environmental Education subjects are books, literature, videos, interviews with experts and practices. According to [12], the cone of experience put forward by Edgar Dale illustrates that a person's learning outcomes are obtained through direct (concrete) experience, realities that exist in one's life and then through artificial objects, to verbal (abstract) symbols. The farther up the top of the cone the more abstract the medium for conveying the message. It can be said that in order to provide maximum experience in the learning environment for students, a good learning medium is to practice direct experience.

\subsection{Learning process}

The learning process is an activity that plays a role in determining the success of the learning outcomes of students. From the learning process there will be reciprocal activities between students and teachers towards predetermined goals. This is as stated by [13] that the learning process is a process in which there are interaction activities between teacher-students and reciprocal communication that takes place on educational sites to achieve learning goals. The success of the implementation of the learning process is an indicator of the implementation of the curriculum made by educators, so that in the learning process, the teacher as educator must create a conducive learning atmosphere. This, as expressed by the AP UPI Lecturer Team (2013), should not apply one method, but teachers must be able to apply various methods so that the learning process takes place pleasantly and achieves the planned goals.

The learning process in Adiwiyata schools in Balangan Regency uses various methods. These methods include group discussions, question and answer, literature study in the library and field observations. With the variety of methods used, it is expected to affect student learning outcomes. The expected learning outcomes are in the form of moral development (affective), skills development (psychomotor), and intellectual development (cognitive). This is as expressed by [14] that learning outcomes in a broader sense include the cognitive, affective and psychomotor fields. Learning activities at The school that runs Adiwiyata in Balangan Regency, is preceded by prayer and students are given an apperception in the form of initial knowledge about matters related to the material. Then the activity continued with activities to observe, ask questions, collect data, associate, and communicate. Learning activities by strengthening the material learned by students by providing opportunities for students to ask questions about material that has not been understood.

Adiwiyata is a program that aims to create school members who are responsible for protecting and managing the environment. This is in accordance with the theory of [15] which states that the goal of the Adiwiyata program is a form of manifesting environmental care behavior. Several Adiwiyata components are directly related to the formation of environmental care behavior which is described through three aspects, namely the level of knowledge, attitudes and behavior. What did the Krajhanzl say in accordance with the the results of this research that Adiwiyata program which is run by the school has a positive impact on student attitudes and behavior related to environmental management and protection. This can be seen from the results of the questionnaires that have been distributed to students $38.5 \%$ of the attitudes and behavior were very good, $45 \%$ showed good behavior, and only $12 \%$ showed sufficient behavior.

The results of this study are not much different from the results of research conducted by [4] that in schools that have Adiwiyata shows that $48 \%$ of students have a high level of knowledge, $99 \%$ of students have a good attitude towards the environment, and $79 \%$ of students have good actions towards the environment. Thus there is a relationship between the application of Adiwiyata and the formation of knowledge, attitudes and actions among students

Therefore can be concluded that the application of the Adiwiyata program has proven to be able to make students behave and behave well towards the environment. As is Widaningsih said [2] that formally environmental education is a rational alternative to include environmental education in the curriculum. Environmental education is one of the important factors in success in environmental management and is also a very important means of producing human resources who can implement the principles of sustainable development. Nurjhani and Widodo [2] add that environmental education is needed and must be given to children from an early age so that they understand and do not damage the environment.

\section{CONCLUSION}

From this research it can be concluded that only some schools consistently and continuously implement environment-based curricula and some others only at the beginning of running the Adiwiyata program. In the Learning Implementation Plan (RPP) document it integrates with the values of caring for the environment but it is not implemented properly. Student care for the environment, $38.5 \%$ showed very good concern, $45 \%$ showed concern well, and $12 \%$ showed concern by the criteria enough. In order for the Adiwiyata program to be implemented optimally, it is suggested: 1) Local governments need to make regulations or be included in regional regulations (Perda); 2) For Related Servicesto always provide continuous assistance to schools that run Adiwiyata programs; 3) Give affirmation to all teachers and education personnel to have the same commitment in realizing a caring and environmentally cultured school, and 4) Involving parents in efforts to foster the character 
of caring for the environment of students, so that what is applied at school can be re-applied at home.

\section{REFERENCES}

[1] Wiyono, Pengantar Ilmu Lingkungan. Yogyakarta: Yayasan Obor Indonesia, 2013.

[2] E. Landriany, "Implementasi Kebijakan Adiwiyata Dalam Upaya Mewujudkan Pendidikan Lingkungan Hidup di SMA Kota Malang," J. Kebijak. dan Pengemb. Pendidik., vol. 2, hal. 82-88, 2014.

[3] R. Sukma, Syahrul dan Indriyani, "No Title," Enviromental Educ. Disaster Mitig. Through Languange Learn., hal. 314, 2019.

[4] I. Rizky Dewi dan W. U. Suyud, "Evaluasi Penerapan Program Adiwiyata Untuk Membentuk Perilaku Peduli Lingkungan di Kalangan Siswa (Kasus: SMA Negeri 9 Tangerang Selatan dan MA Negeri 1 Serpong)," J. Ilmu Lingkung., vol. 15, no. 1, hal. 35-41, 2017.

[5] L. Ellen, "Implementasi Kebijakan Adiwijaya dalam Upaya Mewujudkan Pendidikan Lingkungan Hidup di SMA Kota Malang," J. Kebijak. dan Pengemb. Pendidik., vol. 2, no. 1, 2014.

[6] Wirakusumah, Konsep pendidikan lingkungan di sekolah: model uji coba sekolah berwawasan lingkungan. Bandung: FMIPA Universitas Pendidikan Indonesia.
[7] S. Hamzah, Pendidikan lingkungan sekelumit wawasan pengantar. Bandung: Refika Aditama, 2013.

[8] N. Ngainun, Character Building Optimalisasi Peran Pendidikan dalam Pengembangan Ilmu \& Pembentukan Karakter Bangsa. Yogkayarta: ArRuzz Media, 2012.

[9] H. Haris, Metodologi Penelitian Kualitatif untuk Ilmu-Ilmu Sosial. Jakarta: Salemba Humanika, 2010.

[10] F. Ahmad, "Analasis Impelementasi Kebijakkan Kurikulum Berbasis Lingkungan Hidup Pada Program Adiwiyata Mandiri,” Ejournal UMM., 2014.

[11] N. Amos, Kesadaran lingkungan. Jakarta: PT. Rineka Cipta, 2008.

[12] A. Arsyad, Media Pembelajaran. Jakarta: PT. Raja Grafindo Persada, 2002.

[13] Rustaman, Keterampilan Bertanya dalam Pembelajaran IPA." dalam Handout Bahan Pelantikan Guru-Guru IPA SLTP Se-Kota Bandung di PPG IPA. Jakarta: Depdiknas, 2001.

[14] S. Nana, Cara Belajar Aktif dalam Proses Belajar Mengajar. Bandung: Sinar Baru Algesindo, 2009.

[15] Krajhanzl, "Environmental and pro environmental behaviour," Sch. Heal. J., vol. 21, hal. 251-274, 2010. 